\title{
A STUDY ON FACTORS INFLUENCING YOUNG CONSUMERS' SMARTPHONE BRAND PREFERENCE IN ERZURUM, TURKEY
}

\author{
Ali Kemal Çelik', Hakan Eygü, Erkan Oktay
}

Atatürk University, Erzurum, Turkey

\section{ABSTRACT}

Young consumers are the most important users of advanced information and communication technologies among others. Particularly, since the gradually increasing smartphone use among young consumers is taken into consideration, an empirical evidence about their purchase behavior in terms of brand perception may contribute to the existing marketing literature. For this purpose, the main objective of this paper is to determine factors that may possibly contribute to young consumers' smartphone brand preference in a developing country with a particular emphasis on undergraduate students in Turkey. A written-questionnaire is conducted among 1,135 undergraduate students at a well-established university in Turkey. The dependent variable of this study is smartphone brand with a four-category. The data are analyzed using a multinomial logit model due to the unordered nature of the dependent variable. Estimation results suggest monthly individual income and smartphone use in years have an increasing and decreasing impact on the use of a specific brand, respectively. Results also reveal that monthly household income, price of current smartphone, product design, product weight, and after purchase services have both increasing and decreasing influence regarding a specific brand preference. The outcome of this relatively comprehensive study may provide a successful guidance for future marketing strategies and policies.

\section{JEL CLASSIFICATION \& KEYWORDS}

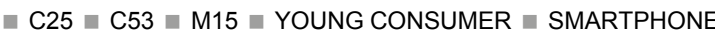
- UNDERGRADUATE STUDENT B BRAND PREFERENCE a MUTINOMIAL LOGIT MODEL — DISCRETE CHOICE MODEL

\section{INTRODUCTION}

The role of consumer characteristics on consumer characteristics have been extensively highlighted to explain consumer's purchasing behavior along with other factors including availability, advertising, and image (Ataman \& Ülengin, 2003; Engel, Blackwell, \& Miniard, 1986). Although predicting a consumer's preference is a relatively difficult task, it gives a valuable information about understanding consumer choice (Bass \& Talarzyk, 1972). In that sense, consumer's perception of the brand is considered as a key concept for brand acceptance, while the level of association between the consumer and the brand will substantially reflect the satisfaction of consumer's needs and the brand's functional attributes (Ataman \& Ülengin, 2003; Hankinson \& Cowking, 1993). The concept of brand equity has been emerged in the marketing literature to define the association between consumers and brands, which is also considered as a measure of the strength of consumers' attachment to a brand (Feldwick, 1996; Wood, 2000).As high brand equity provides firms a variety of privileges such as a more competitive advantage and the opportunity for possible successful extensions (Sasmita \& Mohd Suki, 2015), brand I akemal.celik@atauni.edu.tr

www.journals.cz managers have to manage and evaluate the association between their brands and the meanings that consumers associate with such brands (Jamal \& Goode, 2001), whereas the brand provides consumers with both functional and emotional benefits, and satisfaction (Nguyen, Barrett, \& Miller, 2011).

Mobile communication services have the highest importance among other telecommunication services in the past decades (Dagli \& Jenkins, 2016). Particularly, smartphones have been emerged as the most rapidly growing market segment in the telecommunication industry (Cecere, Corrocher, \& Battaglia, 2015), by means of their more advanced computing ability and connectivity including advanced functions such as portable media players, digital and video cameras, etc. (Mohd Suki, 2013b). Moreover, smartphones are explicitly distinguished from standard mobile phones in terms of their operating system and their purpose of use such as social networking, reading e-books, replying e-mails, browsing information, shopping, entertainment and other featured functions (Liu \& Liang, 2014; Wang, Wang, Gaskin, \& Wang, 2015). Since smartphones are considered as a perceived necessity for consumers, there has been a substantially increasing demand in the smartphone demand (Mohd Suki, 2013b). The recent developments of advanced operating systems, numerous applications, and competition in the telecommunication market have led to a significant increase in the number of smartphone users (N. Park, Kim, Shon, \& Shim, 2013). According the latest forecasts (Statista, 2015), the number of smartphone users worldwide are expected to be almost 2.16 and 2.56 billion people in 2016 and 2018, respectively. Another most recent smartphone shipments forecast (International Data Corporation, 2015) exhibits that smartphone shipments are expected to grow $10.4 \%$ in 2015, while Android has the largest market share with an expected $81.1 \%$ market share in terms of operating systems. The telecommunication sector has the largest share in the electronic devices market in Turkey along with the high demand to smartphones. Numerically, the telecommunication sector has shown an almost $31 \%$ growth in the second quarter of 2015 with respect to the same quarter in 2014 , while the market share of $4 \mathrm{G}$ supporting smartphones increases up to $50 \%$ (GfK, 2015).This rapid adoption of smartphones and overwhelming development of mobile applications have been changing the consumer's behavior for the interaction of a smartphone brand (S. J. Kim, Wang, \& Malthouse, 2015).

Since technology is embedded into students' lives (Dahlstrom, Walker, \& Dziuban, 2014), they are recognized as the most important consumers of college and university information technology services (Dahlstrom \& Brooks, 2014). A recent comprehensive survey in the US colleges reveals that the ownership of smartphones among undergraduate students is $86 \%$ in 2014 up from $76 \%$ since the previous year and at much higher rates than the general adult population (Dahlstrom \& Brooks, 2014). Furthermore, 
most recent consumer surveys (Deloitte, 2014a, 2014b) confirm that $18-24$ years age-group has the highest penetration in terms of smartphone ownership with $85 \%$ in Finland and the UK. Similarly, the results of Deloitte's Turkish Mobile Consumption Survey, 2013 highlight that smartphone use is the highest among $25-34$ age group with 73\% in 2013 (Deloitte, 2013). Not surprisingly, smartphone brand has an important role on younger consumers' rapid smartphone penetration and preference, since consumers' perception of brand image dramatically influences their purchase behavior in the marketplace (Ataman \& Ülengin, 2003). For these purposes, the main objective of this study is to determine factors affecting young consumers' smartphone brand preference with an emphasis on undergraduate students in a Turkish university. The brand preference behavior is especially concentrated on undergraduate students with a comprehensive and reliable survey due to their highest use of technologies, i.e. smartphones, among other consumer groups. Better understanding of the brand preference behavior for such a particular consumer group may provide to implement more specific policies and strategies for smartphone market. A benchmarking of similar studies may confirm the strong association of several analogous factors and smartphone use among young consumers. Thus, more decisive and effective marketing policies may be ensured that may substantially facilitate to decrease time and effort spent on such policies. Moreover, the determination of potential economic and other factors on smartphone use among young consumers may give information on explaining their overwhelmingly increasing smartphone dependence. The rest of the paper proceeds as follows. The next section reviews the existing literature that concentrates on factors that may influence consumers' smartphone use. The methodology section introduces the study design, data and the conceptual framework of the multinomial logit model (MNL) performed in the analysis. The results section presents and interprets the outcome of the estimated model. The paper concludes with the discussion of the results and recommendations for decision- and policy-makers.

\section{Literature Review}

Consumers' smartphone purchase intention may be influenced by many demographic and socio-economic indicators. Many earlier studies (Haverila, 2011; Hong, Chiu, \& Huang, 2012; Y. Kim, Briley, \& Ocepek, 2015; S. Y. Lee, 2014; Y.-K. Lee, Chang, Lin, \& Cheng, 2014; Osman, Sabudin, Osman, \& Shiang-Yen, 2011; Osman, Talib, Sanusi, Yen, \& Alwi, 2011; B.-W. Park \& Lee, 2011b; van Deursen, Bolle, Hegner, \& Kommers, 2015) highlighted the relevance of gender on consumers' smartphone use. In contrast, Ismail (2012) found no moderating effect of gender on smartphone adoption in Malaysian students. Other demographic factors such as age-group (Y. Kim et al., 2015; S. Y. Lee, 2014; Osman, Sabudin, et al., 2011; van Deursen et al., 2015), education and income(Y. Kim et al., 2015) were found be effective on smartphone use. Results of a most recent study (S. Y. Lee, 2014) revealed that financial burden has an impact on college students' smartphone adoption. Cost-efficiency was found as a significant behavioral factor that may influence young consumers' mobile device use (Coelho, Meneses, \& Moreira, 2013; Haverila, 2011; Osman, Talib, et al., 2011). On the contrary, Mohd Suki (2013a) put forward that Malaysian studentswere intended to purchase a smartphone though its price was relatively high to enhance their image. Probably, this specific attitude may be interacted with price signalizing theory where consumers consider lower prices as substandard product quality (DelVecchio \& Puligadda, 2012).
Consumers are intended to prefer a product that is perceived as fitting their self-image. Therefore, brand image is fairly crucial for policy-makers in the market for consumer's purchase intention (Ataman \& Ülengin, 2003). In this respect, many earlier studies (Bojei \& Hoo, 2012; Çakır \& Demir, 2014; Mohd Suki, 2013a) also underlined the importance of brand image on consumers' current and future smartphone use. Apart from brand image, user experience and social influence were significantly associated with purchase and repurchase intention of smartphone (Bojei \& Hoo, 2012; Chou \& Yao, 2012; Chun, Lee, \& Kim, 2012; Dube \& Helkkula, 2015; Jin, Yoon, \& Ji, 2013; Mohd Suki, 2013a, 2013b; Osman, Talib, et al., 2011; Verkasalo, López-Nicolás, Molina-Castillo, \& Bouwman, 2010). Prior studies (Joo \& Sang, 2013; K. J. Kim \& Sundar, 2014; Y. Park \& Chen, 2007; Tsai \& Ho, 2013) also found that perceived ease of use encourage consumers' to purchase a smartphone.

Since the majority of undergraduate students are highly interacted with popular technology tools (Junco \& ColeAvent, 2008), smartphone apps are adopted as a key interaction mechanism between the consumer and the smartphone in recent years (Dube \& Helkkula, 2015). Particularly, many earlier studies (Dube \& Helkkula, 2015; S. C. Kim, Yoon, \& Han, 2014) found an evidence on the association between smartphone apps and smartphone use. Perceived usefulness and perceived enjoyment (Verkasalo et al., 2010) were found to be associated with the use of smartphone apps. A most recent study (S. J. Kim et al., 2015) revealed that app adoption and the continued use of the branded app had a remarkable impact on increasing future purchase. Other innovative product features (Çakır \& Demir, 2014; Joo \& Sang, 2013; K. J. Kim \& Sundar, 2014 Osman, Talib, et al., 2011; Ömürbek \& Şimşek, 2012; Puad, Yusof, \& Sahak, 2016; Tan, Yeh, Chen, Lin, \& Kuo, 2012; Tan, Yi-Der Yeh, Lin, \& Kuo, 2012; Tsai \& Ho, 2013)were also found to be decisive on purchase intention. One study (Böhm, Adam, \& Farrell, 2015) have unveiled the significant role of operating systems on smartphone purchase decisions. Unfortunately, the advanced technologies have some disadvantages and nowadays, information and communication technologies managed to take the control of human life in one sense (Bicen \& Arnavut, 2015).

Among these technologies, smartphone use can be definitely linked to have negative behavioral aspects (Haverila, 2011) such as smartphone dependency. Along with social influences and social needs (Mohd Suki, 2013b), social networking on smartphones was observed as one of the main triggers of smartphone dependency among a wide variety of tasks (Jeong, Kim, Yum, \& Hwang, 2016; Salehan \& Negahban, 2013). Perceived enjoyment, satisfaction with smartphones and personal innovativeness were also found as main indicators of compulsive smartphone use (B.-W. Park \& Lee, 2011a). Earlier work (Ding, Fong Lim, Siuly Patanmacia, Gie Low, \& Ker, 2011) found a strong evidence between smartphone dependency and future purchase behavior.

Method

\section{Multinomial Logit Model}

The dependent variable of this study has a four-category (brand names) with unordered responses and the MNL model is the most frequently used technique to analyze categorical data with unordered choices. The MNL model can be formally written as

$$
\ln \Omega_{m b}(x)=\ln \frac{\operatorname{Pr}(y=m \mid x)}{\operatorname{Pr}(y=b \mid x)}=x \beta_{s p \mid b} \quad \text { for } \mathrm{m}=1 \text { to } \mathrm{J}
$$


where $\mathrm{y}$ is the dependent variable with $\mathrm{J}$ nominal outcomes and $\mathrm{b}$ denotes the base category, which is also considered as the comparison group. The $J$ equations can be solved to calculate the predicted probabilities (J Scott Long \& Freese, 2006):

$$
\operatorname{Pr}(y=m \mid x)=\frac{\exp \left(x \beta_{m b b}\right)}{\sum_{j=1}^{J} \exp \left(x \beta_{j \mid b}\right)}
$$

The discrete choice model bases on the principle that an individual chooses an alternative maximizing the utility gained from the corresponding choice. Since there are $\mathrm{J}$ choices, the probability of choice $m$ is given by

$$
\operatorname{Pr}(y=m)=\operatorname{Pr}\left(u_{m}>u_{j} \text { for } j \neq m\right)
$$

Suppose that $\operatorname{Pr}\left(y_{i}=m \mid x_{i}, \beta_{2}, \ldots, \beta_{J}\right)$ represents the probability of observing $y_{i}=m$ given $x_{i}$ with parameters from $\beta_{2}$ to $\beta_{J}$ and $p_{i}$ represents the probability to observe whatever value of $y$ was actually observed for the ith observation. Since the observations are dependent, the likelihood equation is defined as

$$
L\left(\beta_{2}, \ldots, \beta_{J} \mid y, \mathrm{X}\right)=\prod_{i=1}^{N} p_{i}
$$

The log-likelihood equation that can be maximized to estimate the $\beta$ 's is obtained by taking logs (J. S. Long, 1997). The MNL model assumes a crucial property that the relative odds between two alternative outcomes depend exclusively on characteristics pertaining to the two outcomes and therefore independent of the number and the nature of all other outcomes that are simultaneously evaluated. This special assumption is known as the independence of irrelevant alternatives (IIA) assumption. The null and alternative hypotheses used for the IIA assumption can be given by as the following (Powers \& Xie, 2008):

$\mathrm{H}_{0}$ : The odds of $\mathrm{J}$ and $\mathrm{K}$ response variables are independent with other alternatives.

$\mathrm{H}_{1}$ :The odds of $\mathrm{J}$ and $\mathrm{K}$ response variables are not independent with other alternatives

Such hypotheses are separately tested for all independent variables used in the estimated model.

A marginal effect is defined as the change in the dependent variable per unit change in the independent variable (Powers \& Xie, 2008). Similar to a marginal effect approach, elasticities are frequently calculated to measure the magnitude the impact of specific variables on the outcome probabilities. For indicator variables, a pseudoelasticity can be calculated to estimate an approximate elasticity of the variables which gives the incremental change in frequency associated with changes in the indicator variables. The pseudo-elasticity can be defined as the following:

$$
E_{x_{k l}}^{\lambda_{i}}=\frac{\exp \left[\Delta \beta_{\mathrm{i}} \mathrm{X}_{\mathrm{i}}\right] \sum_{\forall I} \exp \left(\beta_{k l} x_{k l}\right)}{\exp \left[\Delta\left(\beta_{\mathrm{i}} \mathrm{x}_{\mathrm{i}}\right)\right] \sum_{\forall I_{n}} \exp \left(\beta_{k l} x_{k l}\right)+\sum_{\forall I \neq l_{n}} \exp \left(\beta_{k l} x_{k l}\right)}-1
$$

In Equation (5), $\mathrm{x}_{\mathrm{ki}}$ is the value of variable $\mathrm{k}$ for outcome $\mathrm{i}$, $\lambda_{i}$ is the expected frequency for observation $\mathrm{i}, \beta_{\mathrm{i}}$ is a vector of estimable parameters, $X_{i}$ is a vector of explanatory parameters, $I_{n}$ is the set of alternate outcomes with $x_{k}$ in the function that determines the outcome and $I$ is the set of all possible outcomes (Washington, Karlaftis, \& Mannering, 2010).

www.journals.cz

\section{Study Design, Sample and Data Collection}

The aim of the paper is to determine socio-demographic and socio-economic factors that may influence consumer's smartphone brand preference. As young consumers have the highest smartphone penetration in the market place, the particular emphasis is placed on undergraduate students at a well-established university in Turkey. Established in 1957, Atatürk University is the seventh oldest university in Turkey with respect to the number of students an experienced academic staff (Günay \& Günay, 2011). The data for this paper was obtained by a written-questionnaire conducted among 1,135 undergraduate students at Atatürk University between May and June 2015. The underlying questionnaire had two main sections. First section involved questions about students' socio-demographic and socio-economic information such as age-group, monthly income, educational status smartphone use, and other questions about mobile and other telecommunication channel use. Second section investigated the impact of recent innovative feautures of their smartphone on their purchase behaviour in a five-point Likert scale from 'definitively ineffective' to 'definitely effective'. All brands involved in the questinnaire provide the highest standards to Turkish consumers with their important impacts on the smartphone market and the three most frequently used brands were included in the final estimated MNI with the other brand category as well. According to the Turkish Council of Higher Education statistics the number of undergraduate students at Atatürk University was 42,422 during the sample period (Turkish Council of Higher Education, 2015). The data are obtained using a strafied sampling method and 1,135 respondents exceed the number of minimum sample size, which is calculated as 387 and 874 for $7 \%$ and $3 \%$ tolerance, respectively (see Yamane (1967) for details about the calculation of the minimum sample size for such a sampling method).

The dependent variable of this study is the current smartphone brand as a four-category nominal variable. As such a classification does not have a natural ordering, a non-ordered discrete choice model is used to analyze the data, namely the MNL model. In addition, fourteen independent variables are included in the study which do not have a serious multicollinearity issue.

\section{Results}

\section{Descriptive statistics}

Table 1 presents descriptive statistics of dependent and independent variables used in the analysis. As Table 1 indicates, almost half of the respondents preferred Brand $A$ and more than $28 \%$ of them preferred other smartphone brands. More than half of the respondents were aged between 20 and 22, almost $60 \%$ of them were female. Nearly $35 \%$ of undergraduate students were studying at social sciences and almost $29 \%$ of them were sophomores. Almost $26 \%$ of the respondents had monthly income between 301 and 400 Turkish Liras (TL), while more than $31 \%$ of them had more than 2,500 TL monthly household income. More than $41 \%$ of undergraduate students' price of current smartphone was between 501 and 1000 TL, while a majority of them did not intend to purchase a new smartphone. Almost $45 \%$ of the respondents were one or two-year(s) smartphone users. On one hand, almost $42 \%$ and $48 \%$ of the respondents think that price and technical features are effective for their current smartphone purchase, respectively. On the other hand, nearly $46 \%$ and $39 \%$ of the respondents consider that smartphone apps and product design were effective for their smartphone purchase decision. Almost $34 \%$ of the respondents underlined the impact of product weight on smartphone purchase behavior, 
while $40 \%$ of them put emphasis on the role of screen size for their preference. Finally, $37 \%$ of the respondents have drawn attention on after purchase services when purchasing a smartphone.

\section{Estimation results}

Table 2 introduces the estimation results of the fitted MNL model to determine factors that may possibly influence undergraduate students' smartphone brand preference. The model fits well at the $95 \%$ confidence interval and above $\left(p<0.01\right.$, pseudo- $\left.R^{2}=0.1021\right)$ with no serious multicollinearity issue. According Small-Hsiao test (Small \& Hsiao, 1985), the model does not violate the IIA assumption. For simplicity and brevity, only statistically significant variables are presented in Table 2. Additional Wald and likelihood-ratio tests confirm the significance of such variables. Other brand category of the dependent variable was held as the base category with coefficients restricted at zero.

Table 3 exhibits average direct pseudo-elasticities of independent variables. Both the outcome of Table 2 and Table 3 are simultaneously interpreted to examine the results in terms of odds and percentages as well. As shown in Table 2, four independent variables were found as statistically significant including monthly household income, price of current smartphone, impact of product weight, impact of after purchase services. Specifically, undergraduate students who have 1,501-2,000 TL monthly household income are almost 4.6 times $(R R R=4.57, p<.01$, $95 \% \mathrm{Cl}=1.86-11.3$ ) more likely to prefer Brand $\mathrm{A}$ than other brand category. Table 3 indicates that the probability of preferring Brand A increases by $13.15 \%$ when undergraduate students have $1,501-2,000$ TL monthly household income. A similar result holds for undergraduate students who have more than 2,500 TL monthly household income, where they are almost 4 times $(R R R=3.91, p<.01$, $95 \% \mathrm{Cl}=1.59-9.59)$ more likely to prefer Brand $A$ than other brand category. An average direct pseudo-elasticity outcome confirms such a positive association since the probability of undergraduate students' Brand A preference increases by $18.2 \%$ with more than 2,500 TL monthly household income.

Undergraduate students who have monthly household income between 2,001 and 2,500 TL are nearly 3.4 times $(\mathrm{RRR}=3.38, \mathrm{p}<.01,95 \% \mathrm{Cl}=1.36-8.38)$ more likely to prefer a Brand A smartphone than the base brand category. The probability of preferring Brand $A$ increases by $8.9 \%$ for the underlying monthly household income level. Finally, undergraduate students who have $501-1,000 \mathrm{TL}$ and 1,001 $\mathrm{TL}$ and 1,500 TL are both almost 2.7 times more likely to have a Brand A preference than other category. The probabilities of having a Brand A smartphone for such monthly household income levels increase by $4.9 \%$ and $7.4 \%$, respectively.

Undergraduate students' current smartphone prices are found to have a statistically significant impact on their Brand A preference. Accordingly, undergraduate students, whose smartphone price is $500 \mathrm{TL}$ and less, are almost 2.7 times $(\mathrm{RRR}=4.57, \mathrm{p}<.05,95 \% \mathrm{Cl}=1.17-6.09)$ more likely to prefer Brand A smartphones than other brands. Estimation results also reveal that there is a negative association between the impact of product weight and Brand $\mathrm{A}$ smartphone preference. The outcome of the MNL model puts forward that undergraduate students who consider product weight as a definitely effective indicator of smartphone purchase are almost 0.8 times $(R R R=0.83$, $\mathrm{p}<.01,95 \% \mathrm{Cl}=0.72-0.95$ ) less likely to prefer Brand A

\begin{tabular}{|c|c|c|c|c|c|}
\hline Variables & Freq. & Percent & Variables & Freq. & Percent \\
\hline \multicolumn{3}{|l|}{ Brand } & \multicolumn{3}{|c|}{ Smartphone use (in years) } \\
\hline Brand $\mathrm{A}$ & 572 & 47.75 & Less than a year & 186 & 16.39 \\
\hline Brand B & 130 & 11.45 & 1 - 2 year(s) & 506 & 44.58 \\
\hline Brand C & 144 & 12.69 & $3-4$ years & 348 & 30.66 \\
\hline Other branda & 319 & 28.1 & More than 4 years & 91 & 8.02 \\
\hline \multicolumn{3}{|l|}{ Age-group } & \multicolumn{3}{|l|}{ Impact of price } \\
\hline Younger than 20 years & 273 & 24.05 & Definitely ineffective ${ }^{a}$ & 114 & 10.04 \\
\hline $20-22$ years & 599 & 52.78 & Ineffective & 131 & 11.54 \\
\hline $23-25$ years & 242 & 21.32 & Neutral & 131 & 11.54 \\
\hline Elder than 25 yearsa & 21 & 1.85 & Effective & 471 & 41.5 \\
\hline \multicolumn{3}{|l|}{ Gender } & Definitely effective & 288 & 25.37 \\
\hline Male & 451 & 39.74 & \multicolumn{3}{|c|}{ Impact of technical features } \\
\hline Femalea & 684 & 60.26 & Definitely ineffective ${ }^{\mathrm{a}}$ & 54 & 4.76 \\
\hline \multicolumn{3}{|l|}{ Faculty } & Ineffective & 50 & 4.41 \\
\hline Applied sciences & 216 & 19.03 & Neutral & 61 & 5.37 \\
\hline Social sciences & 391 & 34.45 & Effective & 547 & 48.19 \\
\hline Educational sciences & 245 & 21.59 & Definitely effective & 423 & 37.27 \\
\hline Health sciences & 283 & 24.93 & \multicolumn{3}{|c|}{ Impact of smartphone apps } \\
\hline \multicolumn{3}{|l|}{ Class standing } & Definitely ineffective ${ }^{a}$ & 53 & 4.67 \\
\hline Freshman ${ }^{\mathrm{a}}$ & 259 & 22.82 & Ineffective & 48 & 4.23 \\
\hline Sophomore & 328 & 28.9 & Neutral & 71 & 6.26 \\
\hline Junior & 235 & 20.7 & Effective & 523 & 46.08 \\
\hline Senior/Supersenior & 313 & 27.58 & Definitely effective & 440 & 38.77 \\
\hline \multicolumn{3}{|l|}{ Monthly individual income } & \multicolumn{3}{|c|}{ Impact of product design } \\
\hline $100 \mathrm{TL}$ and less $\mathrm{a}$ & 72 & 6.34 & Definitely ineffective ${ }^{a}$ & 71 & 6.26 \\
\hline $101 \mathrm{TL}-200 \mathrm{TL}$ & 78 & 6.87 & Ineffective & 77 & 6.78 \\
\hline $201 \mathrm{TL}-300 \mathrm{TL}$ & 202 & 17.8 & Neutral & 126 & 11.1 \\
\hline $301 \mathrm{TL}-400 \mathrm{TL}$ & 299 & 26.34 & Effective & 447 & 39.38 \\
\hline $401 \mathrm{TL}-500 \mathrm{TL}$ & 205 & 18.06 & Definitely effective & 414 & 36.48 \\
\hline More than $500 \mathrm{TL}$ & 279 & 24.58 & Impact of product we & ight & \\
\hline \multicolumn{3}{|c|}{ Monthly household income } & Definitely ineffective ${ }^{a}$ & 136 & 11.98 \\
\hline $500 \mathrm{TL}$ and less ${ }^{\mathrm{a}}$ & 35 & 3.08 & Ineffective & 143 & 12.6 \\
\hline $501 \mathrm{TL}-1000 \mathrm{TL}$ & 126 & 11.1 & Neutral & 165 & 14.54 \\
\hline $1001 \mathrm{TL}-1500 \mathrm{TL}$ & 193 & 17 & Effective & 385 & 33.92 \\
\hline $1501 \mathrm{TL}-2000 \mathrm{TL}$ & 222 & 19.56 & Definitely effective & 306 & 26.96 \\
\hline $2001 \mathrm{TL}-2500 \mathrm{TL}$ & 202 & 17.8 & \multicolumn{3}{|l|}{ Impact of screen size } \\
\hline More than $2500 \mathrm{TL}$ & 357 & 31.45 & Definitely ineffective ${ }^{\mathrm{a}}$ & 79 & 6.96 \\
\hline \multicolumn{3}{|c|}{ Price of current smartphone } & Ineffective & 94 & 8.28 \\
\hline $500 \mathrm{TL}$ and less & 282 & 24.85 & Neutral & 95 & 8.37 \\
\hline $501 \mathrm{TL}-1000 \mathrm{TL}$ & 470 & 41.41 & Effective & 456 & 40.18 \\
\hline $1001 \mathrm{TL}-1500 \mathrm{TL}$ & 187 & 16.48 & Definitely effective & 411 & 36.21 \\
\hline $1501 \mathrm{TL}$ - $2000 \mathrm{TL}$ & 127 & 11.19 & \multicolumn{3}{|c|}{ Impact of after purchase services } \\
\hline More than $2000 \mathrm{TL}^{\mathrm{a}}$ & 69 & 6.08 & Definitely ineffective ${ }^{\mathrm{a}}$ & 83 & 7.31 \\
\hline \multicolumn{3}{|c|}{ Intention to purchase of a new smartphone } & Ineffective & 95 & 8.37 \\
\hline Yes & 371 & 32.69 & Neutral & 187 & 16.48 \\
\hline \multirow[t]{2}{*}{$\mathrm{No}^{\mathrm{a}}$} & 764 & 67.31 & Effective & 417 & 36.74 \\
\hline & & & Definitely effective & 353 & 31.1 \\
\hline \multicolumn{6}{|c|}{ a denotes referent category } \\
\hline \multicolumn{6}{|l|}{ Source: Authors } \\
\hline
\end{tabular}

than other brand category. Moreover, the probability of preferring a Brand A smartphone decreases by $19.0 \%$. In contrast, undergraduate students who perceive that after purchase services are remarkably important for their smartphone purchase behavior are 1.2 times $(R R R=1.20$, $p<.05,95 \% \mathrm{Cl}=1.03-1.39$ ) more likely to prefer Brand $\mathrm{A}$ than other brands. The probability of such a specific preference increases by $28.3 \%$ along with the importance of after purchase services. 
A STUDY ON FACTORS INFLUENCING YOUNG CONSUMERS' SMARTPHONE BRAND PREFERENCE IN ERZURUM, TURKEY

\begin{tabular}{|c|c|c|c|c|c|}
\hline Independent variable & Coefficient & Std. Err & z-value & RRR & $95 \% \mathrm{Cl}^{\mathrm{c}}$ \\
\hline \multicolumn{6}{|l|}{ Brand $\mathrm{A}$} \\
\hline \multicolumn{6}{|l|}{ Monthly household income } \\
\hline $501 \mathrm{TL}-1000 \mathrm{TL}$ & 0.989 & 0.475 & 2.08 & $2.69^{\mathrm{b}}$ & $1.06,6.82$ \\
\hline $1001 \mathrm{TL}-1500 \mathrm{TL}$ & 0.982 & 0.457 & 2.15 & $2.67^{\mathrm{b}}$ & $1.09,6.54$ \\
\hline $1501 \mathrm{TL}-2000 \mathrm{TL}$ & 1.52 & 0.46 & 3.3 & 4:57:00 AM & $1.86,11.3$ \\
\hline $2001 \mathrm{TL}-2500 \mathrm{TL}$ & 1.218 & 0.463 & 2.63 & 3:38:00 AM & $1.36,8.38$ \\
\hline More than $2500 \mathrm{TL}$ & 1.363 & 0.458 & 2.98 & $3.91^{\mathrm{a}}$ & $1.59,9.59$ \\
\hline \multicolumn{6}{|l|}{ Price of current smartphone } \\
\hline $500 \mathrm{TL}$ and less & 0.981 & 0.422 & 2.33 & $2.67^{\mathrm{b}}$ & $1.17,6.09$ \\
\hline \multicolumn{6}{|l|}{ Impact of product weight } \\
\hline Definitely effective & -0.182 & 0.068 & -2.66 & $0.83^{\mathrm{a}}$ & $0.72,0.95$ \\
\hline \multicolumn{6}{|c|}{ Impact of after purchase services } \\
\hline Definitely effective & 0.182 & 0.077 & 2.36 & $1.20^{\mathrm{b}}$ & $1.03,1.39$ \\
\hline \multicolumn{6}{|l|}{ Brand B } \\
\hline \multicolumn{6}{|l|}{ Price of current smartphone } \\
\hline $500 \mathrm{TL}$ and less & -2.668 & 0.581 & -4.59 & 12:07:00 AM & $0.02,0.22$ \\
\hline $501 \mathrm{TL}-1000 \mathrm{TL}$ & -2.098 & 0.409 & -5.13 & 12:12:00 AM & $0.06,0.27$ \\
\hline $1001 \mathrm{TL}-1500 \mathrm{TL}$ & -1.476 & 0.429 & -3.44 & 12:23:00 AM & $0.10,0.53$ \\
\hline \multicolumn{6}{|l|}{ Impact of product design } \\
\hline Definitely effective & 0.334 & 0.159 & 2.1 & $1.40^{\mathrm{b}}$ & $1.02,1.91$ \\
\hline \multicolumn{6}{|l|}{ Brand C } \\
\hline \multicolumn{6}{|l|}{ Monthly individual income } \\
\hline $101 \mathrm{TL}-200 \mathrm{TL}$ & 1.322 & 0.611 & 2.17 & $3.75^{\mathrm{b}}$ & $1.13,12.4$ \\
\hline \multicolumn{6}{|l|}{ Price of current smartphone } \\
\hline $500 \mathrm{TL}$ and less & 1.668 & 0.709 & 2.35 & $5.30^{\mathrm{b}}$ & $1.32,21.3$ \\
\hline \multicolumn{6}{|l|}{ Smart phone use (in years) } \\
\hline Less than a year & -1.103 & 0.447 & -2.47 & $0.33^{\mathrm{b}}$ & $0.14,0.80$ \\
\hline $1-2$ year(s) & -0.997 & 0.383 & -2.60 & 12:37:00 AM & $0.17,0.78$ \\
\hline $3-4$ years & -1.047 & 0.388 & -2.70 & 12:35:00 AM & $0.16,0.75$ \\
\hline \multicolumn{6}{|l|}{ Impact of product weight } \\
\hline Definitely effective & -0.226 & 0.093 & -2.42 & $0.80^{\mathrm{b}}$ & $0.66,0.96$ \\
\hline Number of observations & 1,135 & & & & \\
\hline Log-likelihood (intercept) & $-1,384.467$ & & & & \\
\hline Log-likelihood (full model) & $-1,243.143$ & & & & \\
\hline $\operatorname{LR}\left(\mathrm{x}^{2}\right)$ & 282.65 & & & & \\
\hline Pseudo-R² & 0.1021 & & & & \\
\hline Significance & 0 & & & & \\
\hline AIC & $2,684.29$ & & & & \\
\hline BIC & $3,182.69$ & & & & \\
\hline \multirow{2}{*}{\multicolumn{6}{|c|}{$\begin{array}{l}\text { Notes: Other brand category is the base case with coefficient restricted at zero, } \\
\text { a denotes } p<.01 ;{ }^{b} \text { denotes } p<.05 \text {. }\end{array}$}} \\
\hline & & & & & \\
\hline Source: Authors & & & & & \\
\hline
\end{tabular}

According to estimation results, two independent variables are found as having a statistically significant impact on undergraduate students' Brand B preference. Firstly, price of current smartphone is negatively effective on smartphone Brand $B$ purchase among undergraduate students. In other words, when undergraduate students' smartphone costs $500 \mathrm{TL}$ and less, they are 0.07 times (RRR $=0.07, p<.01$, $95 \% \mathrm{Cl}=0.02-0.22$ ) less likely to purchase Brand $\mathrm{B}$ smartphones than other brands. One noteworthy outcome is the decrease for the probability of preferring Brand $\mathrm{B}$ by $78.8 \%$ when the price of smartphone is $500 \mathrm{TL}$ and less Similarly, since the price of undergraduate students' smartphone is between $501 \mathrm{TL}$ and 1,000 TL, they are 0.22 times $(\mathrm{RRR}=0.22, \mathrm{p}<.01,95 \% \mathrm{Cl}=0.06-0.27$ ) less likely to prefer Brand $\mathrm{B}$. The probability of preferring Brand $\mathrm{B}$ significantly decreases by 82.3 with respect to the corresponding smartphone price. Almost analogous results are incidentally observed for the price level of $1,001-1,500$ www.journals.cz

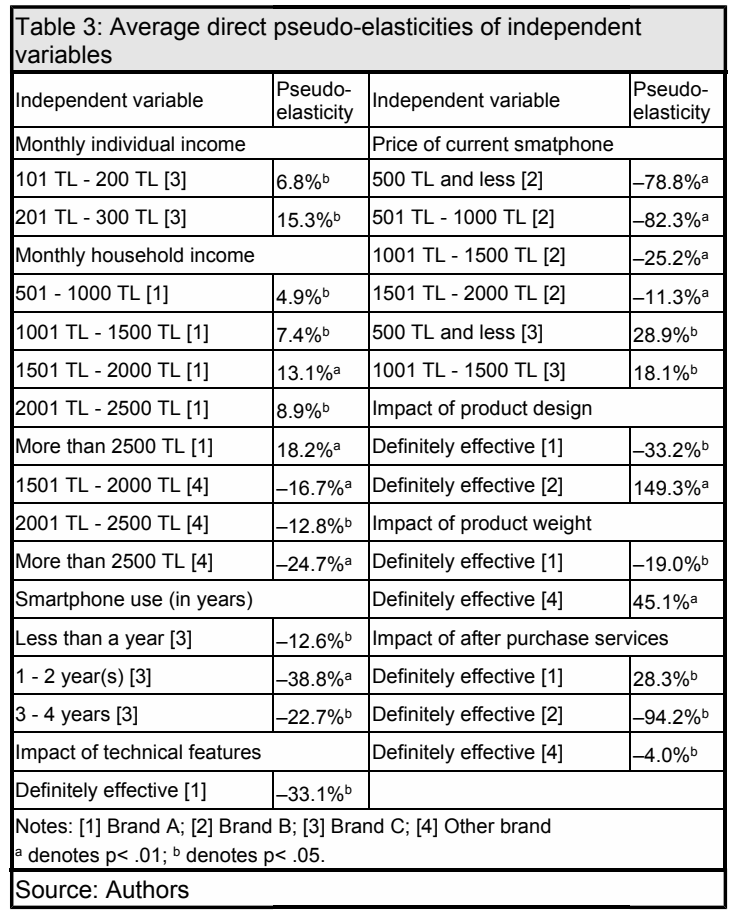

$\mathrm{TL}$, as undergraduate students are 0.23 times $(R R R=0.23$, $\mathrm{p}<.01,95 \% \mathrm{Cl}=0.10-0.53$ ) less likely to purchase Brand B than other category. The probability of such a brand preference also decreases by $25.2 \%$. Secondly, impact of product design is positively associated with undergraduate students' Brand B preference. Numerically, undergraduate students are 1.40 times (RRR $=1.40, \mathrm{p}<.05,95 \% \mathrm{Cl}=1.02-1.91)$ more likely to prefer Brand $\mathrm{B}$, since they adopt that product design is a definitely effective contributor for their purchase. The probability of preferring Brand $B$ has the highest increase by $149.3 \%$ which explicitly explains the association between the impact of product design and Brand B smartphone preference.

Results of the MNL model indicate that four independent variables contribute to undergraduate students' Brand C smartphone preference. Undergraduate students' monthly individual income is found to have a positive impact on their Brand C smartphone purchase. Specifically, when undergraduate students have a monthly income between $101 \mathrm{TL}$ and $200 \mathrm{TL}$, then they are almost four times (RRR $=3.75, p<.05,95 \% \mathrm{Cl}=1.13-12.4)$ more likely to have a Brand $\mathrm{C}$ smartphone than other brand category. The probability of preferring Brand $\mathrm{C}$ also increases by $6.8 \%$. As well as the outcome of Brand $A$ and Brand $B$, price of a current smartphone is found as another key driver of Brand $\mathrm{C}$ preference. When the smartphone is priced as $500 \mathrm{TL}$ and less, undergraduate students are remarkably almost five times $(R R R=5.30, p<.05,95 \% \mathrm{Cl}=1.32-21.3)$ more likely to have a Brand $C$ preference. In parallel with this result, the probability of preferring Brand $\mathrm{C}$ increases by $28.9 \%$.

Smartphone use (in years) is found as a decreasing factor of undergraduate students Brand $\mathrm{C}$ preference. More specifically, undergraduate students who use a smartphone less than a year are 0.33 times $(R R R=0.33, p<.05,95 \%$ $\mathrm{Cl}=0.14-0.80$ ) less likely to prefer Brand $\mathrm{C}$ than other brand category. The probability of preferring the relevant brand decreases by $12.6 \%$. Similarly, one- and two-year 
smartphone users are 0.37 times $(R R R=0.37, p<.01,95 \%$ $\mathrm{Cl}=0.17-0.78$ ) less likely to prefer Brand $\mathrm{c}$. The corresponding probability decreases by $38.8 \%$. Results do not differ much for three- or four-year smartphone users, while they are 0.35 times (RRR $=0.35$, $\mathrm{p}<.01,95 \% \mathrm{Cl}=0.16-0.75)$ less likely to prefer Brand $\mathrm{C}$ than other brands. The probability of preferring Brand C decreases by $22.7 \%$. Finally, a negative association is observed between the impact of product weight and Brand C smartphone preference. Indeed, undergraduate students who perceive product weight as a definitely effective factor are 0.80 times (RRR $=0.80$, $\mathrm{p}<.05,95 \% \mathrm{Cl}=0.66-0.96$ ) less likely to prefer a Brand C smartphone than the base category, namely the other brand.

Table 4 depicts a summary of increasing and decreasing factors of undergraduate students' smartphone preference. Arrows in Table 4 show increase (up) or decrease (down) in average direct pseudo-elasticity with respect to brand names. As shown in Table 4, monthly individual income has an increasing impact on the preference of Brand $\mathrm{C}$, while monthly household income has also such an impact on preferring Brand $\mathrm{A}$ and other brands. According to these results, one can speculate that both brands may revise their marketing strategies to concentrate on al income groups. Estimation results reveal that the probability of preferring Brand $\mathrm{C}$ decreases when smartphone use experience increases. Since undergraduate students do not claim their positive experience in recent years, Brand C may significantly increase their brand image in further years with significantly improved strategies. The same holds for technical features when the preference of Brand A significantly decreases for this variable. The corresponding brand may increase their technical efficiency along with advanced technologies and close monitoring their counterparts in the smartphone market. The probability of Brand $B$ decreases, when the price of smartphone increases in contrast with the evidence of Brand $C$ for the same factor. Product design, weight and after purchase services are other significant factors affecting the probability of preference for specific brand names.

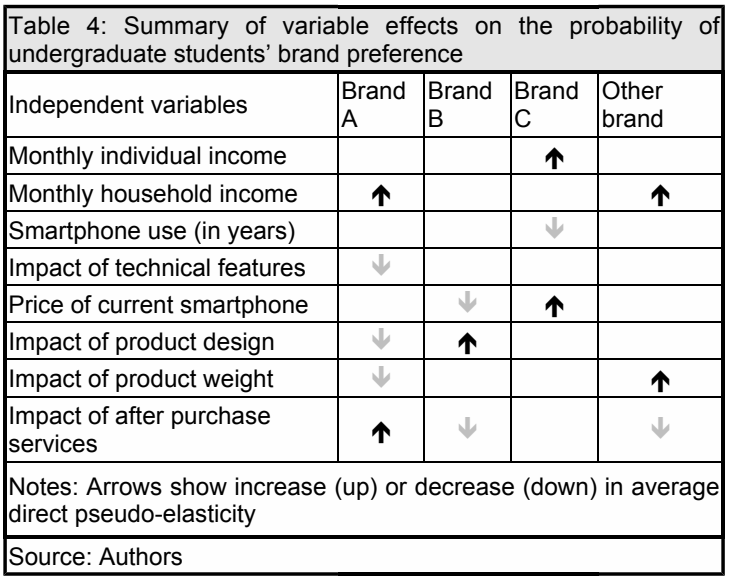

\section{CONCLUSION}

As smartphones are widely accepted as a necessity for human life, any empirical evidence on some popular concepts smartphone engagement, adoption, usage and dependency can be considered as a relatively valuable information for decision- and policy makers in the relevant marketplace. In terms of overwhelmingly increasing smartphone use among younger consumers, the significant contribution of periodical attempts to determine key drivers that may potentially influence their compulsive use cannot be neglected in the existing marketing literature. Since brand image and preference take their respectable place on especially future marketing strategies, better understanding consumers' brand preference behavior will be an actually essential experience for successful future marketing policies. In this manner, this paper mainly purposes to understand factors that may possibly affect young consumers' brand preference. Undergraduate students are principally taken into consideration owing to their relatively compulsive use among others. The data obtained by a comprehensive survey are analyzed using the MNL model which is frequently used to explain certain consumer preference and behavior.

Estimation results suggest that there is a strong relationship between monthly individual and household income and undergraduate students' brand preference. The corresponding outcome in line with some earlier work (Y. Kim et al., 2015; S. Y. Lee, 2014), where individuals' financial situation are under consideration as a significant contributor of smartphone use. Socio-economic factors should be automatically taken account of many consumer purchase behavior by marketing policy-makers regardless of product features. Future marketing strategies may capture for more comprehensive market segments that concentrate on various consumers with different income levels. Such strategies may even involve additional campaigns that may easily attract both low- and high-income potential consumers. Another suggestion of this study is the association between price of current smartphone and brand preference in parallel with recent studies (Coelho et al., 2013; Haverila, 2011; Osman, Sabudin, et al., 2011). Successful cost-efficient marketing strategies may be also proceeded in the future by not damaging brand or product image. Thus, consumers with low-price expectations may perceive themselves as valuable in the smartphone market even if with their constrained budgets. As a generally constrained-budget consumer, students deserve a particular emphasis through improved forthcoming opportunities to encourage them involving in the wide smartphone market. Smartphone use (in years) found in this study can be linked with the results of some other studies (i.e. (Bojei \& Hoo, 2012; Mohd Suki, 2013a, 2013b; Verkasalo et al., 2010) concerning user experience. In that point, policy-makers may increase the number of periodical surveys that provide varying expectations of consumers and benchmarking option for future marketing strategies. The study also highlights the impact of several innovative features such as product weight, design, after purchase services as well as prior research (i.e. Çakır \& Demir, 2014; Joo \& Sang, 2013; Tsai \& Ho, 2013). In the technology era, decision- and policy-makers are virtually obliged to follow the most recent technological advances to keep their positions in the marketplace. Ongoing up-to-date and user-friendly innovative product features may contribute to keep brand image and to increase consumers' brand preference.

This study has some limitations. The study is carried out in a limited time period with an emphasis on undergraduate students. However, the survey is relatively comprehensive and representative to understand students' most recent expectations from smartphone market. Further similar studies addressing consumers' smartphone brand preference may be considered as a worthy benchmarking opportunity in terms of future strategies and policies. Hence, the impact of some other variables including gender and age-group may be better understood. Further research may 
also involve and examine socio-economic aspects of increasing smartphone use. In the context of unordered discrete choice models, a comparison of several models such as the MNL, mixed and nested logit or probit models may be performed to better demonstrate the heterogeneity of consumers' behavior.

\section{REFERENCES}

Ataman, B., \& Ülengin, B. (2003). A note on the effect of brand image on sales. Journal of Product \& Brand Management, 12(4), 237-250. DOI: $10.1108 / 10610420310485041$

Bass, F. M., \& Talarzyk, W. W. (1972). An attitude model for the study of brand preference. Journal of Marketing Research, 93-96.

Bicen, H., \& Arnavut, A. (2015). Determining the effects of technological tool use habits on social lives. Computers in Human Behavior, 48, 457-462. DOI: 10.1016/j.chb.2015.02.012

Bojei, J., \& Hoo, W. C. (2012). Brand equity and current use as the new horizon for repurchase intention of smartphone. International Journal of Business and Society, 13(1), 33-48.

Böhm, S., Adam, F., \& Farrell, W. C. (2015). Impact of the Mobile Operating System on Smartphone Buying Decisions: A ConjointBased Empirical Analysis Mobile Web and Intelligent Information Systems (pp. 198-210): Springer.

Cecere, G., Corrocher, N., \& Battaglia, R. D. (2015). Innovation and competition in the smartphone industry: Is there a dominant design? Telecommunications Policy, 39(3-4), 162-175. DOI: 10.1016/ j.telpol.2014.07.002

Chou, P.-L., \& Yao, C.-H. (2012). The influence of negative word-ofmouth on consumer behavior : The evidence from Taiwan's smartphone users. Journal of Information and Optimization Sciences, 33(4-5), 473-485. DOI: 10.1080/02522667.2012.10700157

Chun, H., Lee, H., \& Kim, D. (2012). The integrated model of smartphone adoption: Hedonic and utilitarian value perceptions of smartphones among Korean college students. Cyberpsychology, Behavior, and Social Networking, 15(9), 473-479. DOI:10.1089/cyber.2012.0140

Coelho, D. C., Meneses, R. F. C., \& Moreira, M. R. (2013). Factors influencing purchase intention of private label products: the case of smartphones Exploring Services Science (pp. 313-321): Springer.

Çakır, F., \& Demir, N. (2014). Üniversite öğrencilerinin akıllı telefon satın alma tercihlerini belirlemeye yönelik bir araştırma (in Turkish). Dokuz Eylül Üniversitesi İktisadi ve İari Bilimler Fakültesi Dergisi, 29(1), 213-243.

Dagli, O., \& Jenkins, G. P. (2016). Consumer preferences for improvements in mobile telecommunication services. Telematics and Informatics, 33(1), 205-216. DOI:10.1016/j.tele.2015.07.002

Dahlstrom, E., \& Brooks, D. C. (2014). ECAR Study of Faculty and Information Technology, 2014 (Louisville, CO: ECAR, July 2014); Eden Dahlstrom and Jacqueline Bichsel. ECAR Study of Undergraduate Students and Information Technology.

Dahlstrom, E., Walker, J., \& Dziuban, C. (2014). ECAR study of undergraduate students and information technology: EDUCAUSE Center for Analysis and Research.

Deloitte. (2013). Türkiye Mobil Tüketici Anketi, 2013 (in Turkish) Available at: https://www2.deloitte.com/content/dam/Deloitte/tr/ Documents/technology-media-telecommunications/tr globalmobile securirtysurvey_infographic.pdf

Deloitte. (2014a). Mobile Consumer 2014: The Finnish Perspective. Available at: http://www2.deloitte.com/content/dam/Deloitte/fi/ Documents/technology-media-telecommunications/Global\% 20Mobile\%20Consumer\%20Survey\%202014_medium.pdf

Deloitte. (2014b). Mobile Consumer 2014: The UK Cut. Available at: http://www.deloitte.co.uk/mobileuk/assets/pdf/Deloitte_Mobile_Con sumer_2014.pdf

DelVecchio, D., \& Puligadda, S. (2012). The effects of lower prices on perceptions of brand quality: a choice task perspective. Journal of Product \& Brand Management, 21(6), 465-474. DOI: 10.1108/10610421211264946

Ding, H. T., Fong Lim, S., Siuly Patanmacia, T., Gie Low, C., \& Ker, C. G. (2011). Dependency on smartphone and the impact on www.journals.cz purchase behaviour. Young Consumers, 12(3), 193-203. DOI: 10.1108/17473611111163250

Dube, A., \& Helkkula, A. (2015). Service experiences beyond the direct use: indirect customer use experiences of smartphone apps. Journal of Service Management, 26(2), 224-248. DOI: 10.1108/JOSM-11-2014-0308

Engel, J. F., Blackwell, R. D., \& Miniard, P. W. (1986). Consumer Behavior: Dryden Press.

Feldwick, P. (1996). Do we really need 'brand equity'? Journal of Brand Management, 4(1), 9-28. DOI: 10.1057/bm.1996.23

GfK. (2015). GfK TEMAX® Türkiye 2015 Íkinci Çeyrek Sonuçları (in Turkish), Press Release. Available at:http://www.gfk.com/tr/newsand-events/press-room/press-releases/sayfalar/tuketici-teknolojisiurunleri-pazari-ikinci-ceyrekte-16-8-buyudu.aspx

Günay, D., \& Günay, A. (2011). 1933'den günümüze Türk Yükseköğretiminde niceliksel gelișmeler (in Turkish). Yükseköğretim ve Bilim Dergisi, 1(1), 1-22. DOI: 10.5961/jhes.2011.001

Hankinson, G., \& Cowking, P. (1993). Branding in action: cases and strategies for profitable brand management: McGraw-Hill Book.

Haverila, M. (2011). Behavioral aspects of cell phone usage among youth: an exploratory study. Young Consumers, 12(4), 310-325. DOI: 10.1108/17473611111185869

Hong, F.-Y., Chiu, S.-I., \& Huang, D.-H. (2012). A model of the relationship between psychological characteristics, mobile phone addiction and use of mobile phones by Taiwanese university female students. Computers in Human Behavior, 28(6), 2152-2159. DOI 10.1016/j.chb.2012.06.020

International Data Corporation. (2015). Worldwide Smartphone Growth Expected to Slow to $10.4 \%$ in 2015, Down From 27.5\% Growth in 2014, Worldwide Quarterly Mobile Phone Tracker, Press Release. Available at: http://www.idc.com/getdoc.jsp?Containerld $=$ prUS 25860315

Ismail, A. R. (2012). Understanding the Factors That Affect the Adoption of Innovative High-Technology Brands: The Case of Apple iPhone in Malaysia. Journal of Global Marketing, 25(4), 226-239. DOI: 10.1080/08911762 2012.753564

Jamal, A., \& Goode, M. M. (2001). Consumers and brands: a study of the impact of self-image congruence on brand preference and satisfaction. Marketing Intelligence \& Planning, 19(7), 482-492. DOI: 10.1108/02634500110408286

Jeong, S.-H., Kim, H., Yum, J.-Y., \& Hwang, Y. (2016). What type of content are smartphone users addicted to?: SNS vs. games. Computers in Human Behavior, 54, 10-17. DOI: 10.1016/ j.chb.2015.07.035

Jin, B. S., Yoon, S. H., \& Ji, Y. G. (2013). Development of a Continuous Usage Model for the Adoption and Continuous Usage of a Smartphone. International Journal of Human-Computer Interaction, 29(9), 563-581. DOI: 10.1080/10447318.2012.729997

Joo, J., \& Sang, Y. (2013). Exploring Koreans' smartphone usage: An integrated model of the technology acceptance model and uses and gratifications theory. Computers in Human Behavior, 29(6). 2512-2518. DOI: 10.1016/j.chb.2013.06.002

Junco, R. \& Cole-Avent, G. A. (2008). An introduction to technologies commonly used by college students. New Directions for Student Services, 2008(124), 3-17. DOI: 10.1002/ss.292

Kim, K. J., \& Sundar, S. S. (2014). Does screen size matter for smartphones? Utilitarian and hedonic effects of screen size on smartphone adoption. Cyberpsychology, Behavior, and Social Networking, 17(7), 466-473. DOI: 10.1089/cyber.2013.0492

Kim, S. C., Yoon, D., \& Han, E. K. (2014). Antecedents of mobile app usage among smartphone users. Journal of Marketing Communications(ahead-of-print), 1-18. DOI: 10.1080/13527266. 2014.951065

Kim, S. J., Wang, R. J.-H., \& Malthouse, E. C. (2015). The Effects of Adopting and Using a Brand's Mobile Application on Customers' Subsequent Purchase Behavior. Journal of Interactive Marketing 31, 28-41. DOI: 10.1016/j.intmar.2015.05.004

Kim, Y., Briley, D. A., \& Ocepek, M. G. (2015). Differential innovation of smartphone and application use by sociodemographics and 
personality. Computers in Human Behavior, 44, 141-147. DOI: 10.1016/j.chb.2014.11.059

Lee, S. Y. (2014). Examining the factors that influence early adopters' smartphone adoption: The case of college students. Telematics and Informatics, 31(2), 308-318. DOI: 10.1016/j.tele.2013.06.001

Lee, Y.-K., Chang, C.-T., Lin, Y., \& Cheng, Z.-H. (2014). The dark side of smartphone usage: Psychological traits, compulsive behavio and technostress. Computers in Human Behavior, 31, 373-383. DOI: 10.1016/j.chb.2013.10.047

Liu, C.-J., \& Liang, H.-Y. (2014). The deep impression of smartphone brand on the customers' decision making. Procedia-Social and Behavioral Sciences, 109, 338-343. DOI:10.1016/j.sbspro.2013. 12.468

Long, J. S. (1997). Regression Models for Categorical and Limited Dependent Variables: SAGE Publications.

Long, J. S., \& Freese, J. (2006). Regression models for categorica dependent variables using Stata: Stata press.

Mohd Suki, N. (2013a). Students' demand for smartphones: Structural relationships of product features, brand name, product price and social influence. Campus-Wide Information Systems, 30(4), 236-248. DOI: 10.1108/CWIS-03-2013-0013

Mohd Suki, N. (2013b). Students' dependence on smart phones: The influence of social needs, social influences and convenience. Campus-Wide Information Systems, 30(2), 124-134. DOI: 10.1108/10650741311306309

Nguyen, T. D., Barrett, N. J., \& Miller, K. E. (2011). Brand loyalty in emerging markets. Marketing Intelligence \& Planning, 29(3), 222 232. DOI: $10.1108 / 02634501111129211$

Osman, M. A., Sabudin, M., Osman, A., \& Shiang-Yen, T. (2011). Consumer Behaviors toward Usage of Smartphone in Malaysia. Paper presented at the 2011 International Conference on Software and Computer Applications.

Osman, M. A., Talib, A. Z., Sanusi, Z. A., Yen, T. S., \& Alwi, A. S. (2011). An exploratory study on the trend of smartphone usage in a developing country Digital enterprise and information systems ( $p p$. 387-396): Springer.

Ömürbek, N., \& Şimşek, A. (2012). Üniversite Öğrencilerinin Cep Telefonu Tercihlerinin Analitik Hiyerarşi Prosesi İle Belirlenmesi. Niğde Üniversitesi İktisadi ve İdari Bilimler Fakültesi Dergisi, 5(1), 116.

Park, B.-W., \& Lee, K. C. (2011a). The effect of users' characteristics and experiential factors on the compulsive usage of the smartphone Ubiquitous computing and multimedia applications (pp. 438-446): Springer.

Park, B.-W., \& Lee, K. C. (2011b). A pilot study to analyze the effects of user experience and device characteristics on the custome satisfaction of smartphone users Ubiquitous Computing and Multimedia Applications (pp. 421-427): Springer.

Park, N., Kim, Y.-C., Shon, H. Y., \& Shim, H. (2013). Factors influencing smartphone use and dependency in South Korea. Computers in Human Behavior, 29(4), 1763-1770. DOI: 10.1016/j.chb.2013.02.008

Park, Y., \& Chen, J. V. (2007). Acceptance and adoption of the innovative use of smartphone. Industrial Management \& Data Systems, 107(9), 1349-1365.

Powers, D. A., \& Xie, Y. (2008). Statistical methods for categorical data analysis: Emerald Group Publishing.

Puad, M. H. M., Yusof, A. R., \& Sahak, S. Z. (2016). Smartphone Product Appearance: What Drive Consumers' Purchase Decision? Paper presented at the Proceedings of the 1st AAGBS International Conference on Business Management 2014 (AiCoBM 2014).

Salehan, M., \& Negahban, A. (2013). Social networking on smartphones: When mobile phones become addictive. Computers in Human Behavior, 29(6), 2632-2639. DOI: 10.1016/ j.chb.2013.07.003

Sasmita, J., \& Mohd Suki, N. (2015). Young consumers' insights on brand equity: Effects of brand association, brand loyalty, brand awareness, and brand image. International Journal of Retail \& Distribution Management, 43(3), 276-292. DOI: 10.1108/IJRDM-022014-0024

www.journals.cz
Small, K. A., \& Hsiao, C. (1985). Multinomial logit specification tests. International economic review, 26(3), 619-627. DOI: $10.2307 / 2526707$

Statista. (2015). Number of smartphone users worldwide from 2012 to 2018 (in billions). Available at:http://www.statista.com/statistics/ 330695/number-of-smartphone-users-worldwide/

Tan, W.-K., Yeh, Y.-D., Chen, S.-J., Lin, Y.-C., \& Kuo, C.-Y. (2012) Using DEMATEL and the smartphone as a case study to investigate how consumers evaluate many features of a product collectively. International Journal of Applied Mathematics and Informatics, 6(3) 117-125.

Tan, W.-K., Yi-Der Yeh, S., Lin, Y., \& Kuo, C. (2012). How Consumers Assess Product's Features?: A Case Study of Product Features of Smartphone. Paper presented at the Proceedings of the 6th international conference on Applied Mathematics, Simulation, Modelling.

Tsai, J.-P., \& Ho, C.-F. (2013). Does design matter? Affordance perspective on smartphone usage. Industrial Management \& Data Systems, 113(9), 1248-1269. DOI: 10.1108/IMDS-04-2013-0168

Turkish Council of Higher Education. (2015). 2014-2015 yılı öğrenci sayıları (in Turkish). Available at: https://istatistik.yok.gov.tr/

Van Deursen, A. J. A. M., Bolle, C. L., Hegner, S. M., \& Kommers, P. A. M. (2015). Modeling habitual and addictive smartphone behavior. Computers in Human Behavior, 45, 411-420. DOI: 10.1016/j.chb.2014.12.039

Verkasalo, H., López-Nicolás, C., Molina-Castillo, F. J., \& Bouwman, H. (2010). Analysis of users and non-users of smartphone applications. Telematics and Informatics, 27(3), 242-255. DOI:10.1016/j.tele.2009.11.001

Wang, J.-L., Wang, H.-Z., Gaskin, J., \& Wang, L.-H. (2015). The role of stress and motivation in problematic smartphone use among college students. Computers in Human Behavior, 53, 181-188. DOI: 10.1016/j.chb.2015.07.005

Washington, S. P., Karlaftis, M. G., \& Mannering, F. L. (2010) Statistical and econometric methods for transportation data analysis: CRC press.

Wood, L. (2000). Brands and brand equity: definition and management. Management decision, 38(9), 662-669. DOI: 10.1108/00251740010379100

Yamane, T. (1967). Elementary Sampling Theory: Prentice-Hall. 